\title{
Artistic Time in M.A. Tarkosky's Small Prose
}

\author{
Nikita A. Valianov* \\ Krasnoyarsk State Pedagogical University \\ named after V.P. Astafiev \\ 89 Ada Lebedeva Str., Krasnoyarsk, 660049, Russia
}

Received 10.01.2017, received in revised form 18.12.2017, accepted 15.01.2018

The article focuses on the problem of artistic time in the small prose by M.A. Tarkovsky, a modern Siberian writer whose work is related to modern traditionalism by the critics and literary scholars. The writer's early and mature texts serve the basis for the general typology of artistic time and revealing its features. Particular emphasis is given to the poetics of crisis and idyllic time in the writer's creative work since a certain transition from chaos and loss of the traditional to the idea of national values is obvious in M.A. Tarkovsky's key texts.

Keywords: artistic time, chronotope, neo-realism, contemporary traditionalistic prose, village prose, small prose, Mikhail Tarkovsky, contemporary Russian literature.

DOI: 10.17516/1997-1370-0214.

Research area: philology.

\section{Introduction to the research} problem

Contemporary Russian literature is at the crossroads nowadays. It is Russian prose at the turn of the $20^{\text {th }}-21^{\text {st }}$ centuries that is particularly exposed to significant changes. According to A.Iu. Bol'shakova, a new benchmark is set in understanding contemporary literary process and its trends (Bol'shakova, 2011). The critics and literary scholars rightly believe that modern Russian literature should be attributed to the transitional period with its new change of cultural paradigms (Cherniak, 2016).

The characters' typology, problems and poetics of works, their ideological and thematic content are subject to significant transformations; a special type of psychologism (when the characters are not only reserved but locked in their secluded world) is established. The literary characters' active desire to understand the limits of the utopian, escape from chaos of civilization, develop their oecumene are quite convincingly traced in the texts. Spatial-temporal connections are often violated in works, which is especially characteristic of postmodern aesthetics. This is currently traced in the texts of modern realism.

The issue of artistic time is still especially important in contemporary literary science. This is primarily due to the change in understanding of time and attitude to it at the turn of the century. In the artistic-aesthetic paradigm time is not only some kind of conditional reality but the category that forms the writer's ideology and often shapes his/her artistic picture of the world. Time helps

(C) Siberian Federal University. All rights reserved

* Corresponding author E-mail address: nick.valyanov@yandex.ru 
the writer outline a different type of hero, define his place in history. In the prose at the turn of the $20^{\text {th }}-21^{\text {st }}$ centuries there remains a possibility of the idyllic type of hero embodiment along with the "borderline" ones (Balashova, 2009; Kovtun, 2011).

\section{Theoretical prerequisites}

There are two fundamental conceptions of space-and-time in literary theory. The first dates back to M.M. Bakhtin's idea, who argues that "time is the leading principle in chronotope" (Bakhtin, 1975: 235). Iu.M. Lotman's position is different from this idea. He insists that "even temporary modeling is often a secondary superstructure of spatial language" (Lotman, 1988: 293). The significant works by the representatives of the Tartu-Moscow school B.A. Uspenskii, S.Iu. Nekliudov, V.N. Toporov are devoted to the issues of artistic time in literary science. Various aspects of the category of artistic time are viewed by P.A. Florenskii, A.Ia. Gurevich, N.K. Gei, G.N. Pospelov, A.B Esin, V.E. Halizev, N.D. Tamarchenko, V.I. Tiupa, S.N. Broitman, A.Ia. Esalnek, et al.

Attitude to time is one of the most important aesthetic principles of the Russian "village prose" (Porte, 2004: 69). Several types of time are characteristic for "classical" traditionalism. Cyclic time (or folk-mythological time, according to M. Bakhtin) is obviously one of the leading types (Kovtun, 2009: 207-260). Historical time is typical of the village prose writers' earliest texts (the works of the "Ovechkin" period) and partly of their mature prose. Biographical time is very important in the traditionalists' literary texts (Stepanova, 2016: 160). K. Parte singles out literary time, time of generations (or time of the inherited memory), time of childhood in the traditionalism prose; apocalyptic (eschatological) time is given a special emphasis by the author (Parte, 2004: 70-71). The latter is likely to correlate with Bakhtin's crisis time, which occurs before the irrational forces intervention (Bakhtin, 2002). V. Rasputin's mature and late prose ("Proshchanie s Materoi" ("Farewell to Matyora"), "Pozhar" ("Fire")) are especially convincing in this respect. Such temporary situation is reflected in certain texts by the neo-traditionalist writers ("Eltyshevy" ("The Eltyshevs"), "Zona zatopleniia" ("Flood Plane") by R. Senchin, "Zatonuvshii Kovcheg" ("The Sunken Ark") by A. Varlamov, "Konets veka" ("The End of the Century") by O. Pavlov, ("Babushkin spirt") "Grandmother's Alcohol", "Ledokhod" ("Ice Drift"), "Stroika Bani" ("Construction of Banya") by M. Tarkovsky).

\section{Problem statement}

The subject of our study will be the artistic time in the prose of M.A. Tarkovsky, a writer of the turn of the century, whose poetics is a sign of the transition from the crisis of national identity to the problem of rethinking the national values. The writer's fiction fixes the movement from $a$ crisis situation to an idyll. The goal set is to work out the typology of the artistic time in the writer's creative work and distinguish specific temporal features inherent in the poetics of his early and mature texts. The following types of the artistic time should be distinguished in the writer's prose: cyclic, biographical, psychological, crisis, idyllic.

\section{Cyclic time}

Cyclic time obviously attaches significance to the structural-poetic system of the traditionalist texts. In M.A. Tarkovsky's artistic prose it is directly linked with the natural change of time cycles (seasons), with the field work, folk customs and traditions. The literary characters' time is closely related to recurrent natural cycles. In spring the characters look forward to ice drift ("Ledokhod" ("Ice Drift"), "Vekovechno" 
("Eternally"), hunting season starts in autumn (“Osen" (“Autumn"), “Les" (“Forest”)), haymaking time is in summer ("Tanya"). These are what the writer's small prose is based on. The cyclic nature of the writer's artistic picture of the world is repeatedly emphasized in the end of his works. According to N.V. Beliaeva, the final paragraph is a strong position of the text, in which the cyclic conception of time "overcomes" the linear one (Beliaeva, 2009).

Cyclic time is characteristic of the "Construction of Banya" story (1998) which marks the writer's mature prose. The plot basis of the story is the construction of a new banya (bathhouse). It is remarkable that the process of the entire estate construction is accompanied by important events in the life of the characters whose memories are embedded in the story. By erecting the house the hero is as if preparing to his own death: he is striking the balance of his life, recalling the sins of the past, preparing a new abode. The final scene of the Exodus (the hero is taking a steam bath) is interpreted as the abandonment of sin, catharsis, finding peace and new life: "All the resentment and annoyance went to his final resting place and Ivanych's sole, which had never been so pure, flew off to heaven" (Tarkovsky, 2014: 183). It is significant that a death event occurs in the early morning, at the start of haymaking and a new life, the scene symbolizing the cyclic nature of existence, characteristic of Russian culture. The tragic end is overcome by the writer's thoughts about the future. The idea of recurrence and infinity of being is stated. In this respect, it should be noted that a new model of time is formed in the texts of the late traditionalism (especially V. Rasputin's ones): a human's existence is not terminated by death, the death itself is conceived as continuation of life but in a different dimension, in a more intimate form (Kovtun, Stepanova, 2015: 144-152).
Like A.N. Varlamov's one, the chronotope of M.A. Tarkovsky's small prose is associated with the "autobiographical hero's utopian search for "the promised land"" (Schastlivtseva, 2007: 4). Autobiographism of M.A. Tarkovsky's prose leads to the occurrence of biographical time in his texts. It is not less relevant to contemporary literature and related to the realistic principles of writing. This type of time finds its most significant reflection in the story "Otdai moe" ("Give Me Mine") (2003), one of the writer's mature autobiographical texts. The text sets out the life story of a young hero Mitia whose life reflects the main events in the writer's life. It is just enough to project the writer's sketchesmemoirs ("Grandmother's Grandchild", "Grey Skirt”) with this story.

Biographical nature of the story highlights not only key events from the hero's life (watershed meetings, disease, death) but also the diary in which Mitia writes his impressions about life every evening. The main hero's life story is shaped by different events and occasions, which do not necessarily have a chronological sequence. Memories become one of the storytelling means. They accompany the plot, create the text "volume". They are what the readers' ideas of the main hero's biography are based on. Thus, indulging in memories, Mitia thinks of his childhood and youth. He recalls how grandma slipped the books about Siberia into him from his early childhood, how his mother drove him in the bathroom one day after he came back lousy from his next taiga expedition.

Mit'ka Glazov's memories about his first creative endeavors, student years, hunting, visits to Orthodox churches, first literary works read by his Grandmother are no less vivid. All the memories are fragmented and disseminated in the course of the writer's narrative. It should be repeated, however, that such fragmentation of the temporal biographic series does not exclude the 
hero's character integrity. On the one hand, we observe Mit'ka's static image group at a certain stage of his life (when he is assigned a field zoologist to the expedition). On the other hand, the key moments of life imprinted in his memory help to plan a certain stage of the hero's maturity. His Grandmother's wise advice and instructions, the father's death, personal relationships with the mother, and other family troubles - all these help the writer form the young hero's value orientations on life and surrounding reality.

His visit to Zhanna, a healer, will help a young hunter comprehend the true meaning of life. "Take what is yours, give me what is mine" is a woman's key phrase that will sound like an order for the deliverance from terrible dreams. It will push the hero to the important thoughts about life and nearly lead to wisdom of acceptance of everything around. His final thoughts which are, in fact, in the strongest position in the story testify of his next stage of life.

When in taiga, Tarkovsky's hero always considers his past. Thus, the so-called memory time is implemented; the biographical retrospection technique is often used. All the specifics of the writer's artistic world are based on the fact that the image of the hero, his character and destiny are built through memories. They become an objective centre of the story, expand the spatial model of the text, and form the writer's attitude (through the hero) to the events and surrounding reality.

\section{Crisis time}

Basing on M. Bakhtin's theoretical reflections, it is worth while noting that crisis time is the last moment of consciousness. It may be equal to years or decades. These are the moment before death or the one before conflict with the mystical powers. Such a flow of time commonly occurs before execution, suicide, intervention of irrational forces (Bakhtin,
2002). K. Parte, in his turn, states the poetics of eschatological (apocalyptic) time in the texts of the late traditionalists and post-village literature. American Slavic studies define their variants of "the end", the variants being death of the elderly, escape from the villages, loss of traditional rural lifestyle and damage caused by nature (Parte, 2004: 105).

The conceptual texts of the early (and partly of the mature) stage of M.A. Tarkovsky's creative work focus on the concepts of loss of national culture, traditions, peasant house, family, which is typical for the late prose of the "villagers". These works are "Ledokhod" ("Ice Drift"), "Vekovechno" ("Eternally"), "Petrovich", "Fundament" ("Foundation") stories, "Babushkin spirt" ("Grandmother's Alcohol”), "Lozhka supa" ("A Spoon of Soup") novels. The texts are pierced with nostalgic motifs; they preserve an idea of a patriarchal village. The writer outlines traditional literary images (a peasant, a folk righteous man, a patriarchal male type) which are gradually replaced with the image of the hero with the crisis thinking.

The ideas of self-sacrifice, individual excommunication, detachment from the world become key ones in the late traditionalists' texts. The motif of leaving/farewell/parting, ideologically inscribed in the historical and literary situation of the turn of the $20^{\text {th }}$ $21^{\text {st }}$ centuries, becomes a plot basis of the artistic narrative. In his "Babushkin spirt" ("Grandmother's Alcohol") story (2004) the writer reconstructs "a motif of a long ordeal". The Grandmother worries about her son, who lapsed into "drunken numbness", and grieves for her unlucky daughter Gal'ka, a "sottish and idle girl” (Rusakov, 2004: 3). Yet, all her heart mostly aches for her grandson Kol'ka who had been "powerfully and forever vaccinated" from illfated vodka since his childhood. The split of the village space into two camps - that of the sober 
and that of the drunken (which are relatively similar to heaven and hell), where "one group plow on one side, yet the others couldn't care less on the other side" (Tarkovsky, 2014: 252), the ones survive at the expense of the others, - is due to the destruction of the traditions, a former way of life. Mystery time is conventionally implemented in the story. M.M. Bakhtin defines this type of time as condescension to the underworld of disasters (Bakhtin, 2002).

One of the key motifs which is already mentioned in the "Construction of Banya" story is the motif of the prodigal son. It is associated with an image of Serega, the protagonist's son who leaves his father's house, gets settled in the hostel while hoping to settle in the city. Ivanych, the protagonist's father, dies in his native dear taiga, still waiting for his son.

The crisis of traditionalism, outlined in Tarkovsky's symbolic texts, designates the character at the turn of the century who will start to search for his own actions justification, spiritual salvation while unselfishly helping his neighbour. The writer shows the foolishness as a sign of the times and whacky Van'ka ("Fundament" ("Foundation") (2004) becomes a personification of the era: "He was very much like a blind lyre or the psaltery player who came from bottomless antiquity to mourn and read the funeral service to our stupid time" (Tarkovsky, 2014: 116). The holy fool's "lamentation" (when the heroes have a heart-to-heart talk and Van'ka refuses to take money for his work on house construction) turns into atonement. "Foundation" will become a landmark product for the writer who, like V. Rasputin, his predecessor, regards the image of intellectual Fedor (who played host to the pilgrim and thus, in fact, prepared Vania to a new life) as a chance for salvation of the present. This type of hero displays the key features of national rural character, the features being justice, conscientiousness, unselfishness, humane attitude to the neighbour. Yet, holding his personal position in the world of chaos, the image is devoid of illusions about the revival of old lifestyle (Kovtun, 2013: 17-26).

\section{Idyllic time}

It is idyllic time that should be stated in M.A. Tarkovsky's prose along with crisis time. It is not just opposed to the crisis of the epoch or human destiny. It is a kind of attempt to overcome chaos and loss. Idyllic time in the writer's artistic system is connected with labour, harmony with nature. Here it mutually intersects with cyclic, routine time. Such time is characteristic of a taiga space. The works often describe the processes of hunting, fishing (the heroes put and dismantle traps, hunt the game, sables, build their own houses). Almost every literary text contains an episode when the heroes are engaged in the taiga development, "domesticate" the geographical space, and make it the space for everyday life.

According to A.A. Mitrofanov, a man in Tarkovsky's artistic world is worth his labour, labour being his main ideological value (Mitrofanova, 2009). Labour is claimed to be the only thing that provides life stability, gives peace and freedom to mind, and makes a person independent and free from other social needs. So, for example, father Ivanych in "Construction of Banya", the writer's key story, gets into an argument with his son and blames him: "What a man you are if you can't do anything", thus believing that "freedom is when one can do everything and isn't dependent on anyone" (Tarkovsky, 2014: 237).

Tarkovsky attaches great artistic value to the heroes' taiga life. He describes tools, specialpurpose machines, boats, ski climbers, various hunting guns. All these are not only poeticized by the him, but attributed a high aesthetic value. Tarkovsky's muzhiks as if "return the items their original holy functional value, which is in helping 
a man in cognizing and further creation of the world", they "strive for perfection in mastering the skill" (Mitrofanova, 2009: 436).

Analyzing M. Tarkovsky's artistic creativity, I.A. Kargashin, his prose researcher, notes that "it is neither a "twist" of the plot, nor a chain of fictional events that strike, but everyday life, routine life in the world of nature and labour" (Kargashin, 2013: 206). The main task for Tarkovsky's hero is to hunt an animal, choose the right net for fishing, chop firewood for the winter, fetch water, feed the dogs. It is clear that the writer considers the process of work to be significant. Its result is also viewed as no less important. In the stories we come across with the fact that the hero hews the boat from aspen, lays the foundation, builds houses and banyas (bath houses), binds rafts, puts traps, fabricates the animals' skin, etc. Taiga becomes the idyllic chronotope where the hero is destined to be reborn, find his destiny.

\section{Psychological time}

This time is considered by M.A. Tarkovsky as a variant of subjective (perceptual) time. This is also mentioned by N.V. Beliaeva in her thesis "The Lyrical Basis in M.A. Tarkovsky's Prose" (Beliaeva, 2009). The researcher argues that in most of the writer's texts time is measured not by specific historic dates, facts or events but the heroes' experiences (Beliaeva, 2009: 128). It's perceived neither by a hero nor by a reader. It is plotless time. Hence, artistic time is often manifested as slow-motion (frozen) time. The hero's time moves slowly and smoothly. It is in harmony with the time of nature. However, the slow leisurely time in the writer's prose serves the background for the heroes to perceive their own life as something rapid and fast sometimes. They view the time of their lives as a "slippery plane which is impossible to drive a crowbar into or catch a hold of no matter how you try" ("S Vysoty" ("From the Height")) or "some messy electric train" (“Lerochka” (“Dear Lera”)) (Beliaeva, 2009: 129).

Quite an interesting time technique is used by M.A. Tarkovsky in the story "Lozhka supa" ("A Spoon of Soup") (1999). In this story transition of time takes place within the main heroes' house limits, which obviously creates a kind of cinematic effect. A lad and his mother, aunt Grania Khokhlova, make a journey into the past. With all this going on real time of action in the story slows down and stops for a moment, gets frozen. The heroes' as if return to the time of Slavka's childhood, idyll, the time when the mother fed her son with the soup cooked from the Yenisei fish: "Uh-h-uh, - the mother sang as if floating far away, - my son sees nothing $<\ldots>$ and so they sat close to each other in the time which was as if frozen and stared with their round prophetic eyes at the red flame of the cellar lit by the sunset, and aunt Grania's pitying, bitter and simultaneously sweet half-smile was as if saying: well, here we are, back from the place we went to. And the mother recalled Slavik, her small and smelling of milk son, and other kids, not her own ones, who turned into the bearded, stinking of vodka and tobacco men long ago..." (Tarkovsky, 2014: 235). There is a symbolic transition in the story, the transition being the hero's transformation - the mother as if gives communion to a hero with a spoon of fish-soup, prepares him to a righteous life. It is not coincidentally that the writer effectively ties the Lad's fate with the image of the Yenisei river in the end of the story. It is the Yenisei "from which we take the example, equal our life like a barge board, and learn to overcome melancholy and illness, endure, tolerate drinking bouts as bad weather, return to life, breathe $<$... " (Tarkovsky, 2014: 237).

\section{Conclusion}

Artistic time in some of the writer's texts has a plot-forming value ("Zamorozhennoe vremia" 
("Frozen Time"), "Za piat' let do schastia" ("Five Years before Happiness"), "Lozhka supa" (“A Spoon of Soup"), "Enisei, otpusti!" ("Yenisei, Let Me Go!"). Temporal modus of M.A. Tarkovsky's artistic system is represented the following way: past-present-future. N.A. Nikolina in "Poetika russkoi avtobiograficheskoi prozy" ("The Poetics of Russian Autobiographical Prose") distinguishes three types of temporal relations (Nikolina, 2002: 340). One of them corresponds to the poetics of M. Tarkovsky's prose: the narrative here is organized with a sustainable reference point on the time axis, the point being the narrator's present; the narrative is characterized by a precise chronological sequence, the narrator's point of view being retrospective. Instability of the boundaries between past and present becomes the most important temporal characteristic feature in
Tarkovsky's prose: all the past events become the object of the hero's momentary reflection, either long or painful memories.

Artistic time in M.A. Tarkovsky's texts is perceived differently, transformed. The writer introduces certain temporal codes (reference to the past, "frozen" (suspended) time effect, transition in time). As for the typology of time, cyclic time in the traditionalist's prose is the main, plot-forming one; it binds man and nature together. Psychological time displays a picture of the world inherent in the heroes' minds. It is connected with their inner world. Biographical time reflects the writer's individual experience. Crisis chronotope in the writer's prose is gradually replaced by the idyllic one, associated with the writer's hopes for creation of new cultural traditions.

\section{References}

Bakhtin, M.M. (1975). Formy vremeni i khronotopa v romane. Ocherki po istoricheskoi poetike [Forms of Time and Chronotope in the Novel. Essays on Historical Poetics], In Voprosy Literatury $i$ Estetiki [Literature and Aesthetics Issues]. Moscow, 234-407.

Bakhtin, M.M. (2002). Problemy poetiki Dostoevskogo. Raboty 1960-1970 gg. [Problems of Dostoevsky's Poetics. Works of 1960-1970]. Moscow, 801 p.

Balashova, E.A. (2009). V.M. Shukshin i M. Tarkovskii: prostranstvo idillicheskogo geroia [V.M. Shukshin and M. Tarkovsky: an Idyllic Hero's Space]. Shukshinskii tekst: opyt prochteniia. Mezhvuzovskii sbornik nauchnykh statei, posviashchennykh vos'midesiatiletiiu V.M. Shukshina [Shukshin's Text: the Experience of Interpretation. Interuniversity Collection of Scientific Articles Devoted to V.M. Shukshin's Eightieth Anniversary]. Barnaul, 50-57.

Beliaeva, N.V. (2009). Liricheskoe nachalo v proze M.A. Tarkovskogo [The Lyrical Basis in M.A. Tarkovsky's Prose]. Ussuriisk, 191 p.

Bol'shakova, A.Iu. (2011). Russkaia literature na rubezhe XX-XXI vv.: novye prioritety [Russian Literature at the Turn of $20^{\text {th }}-21^{\text {st }}$ Centuries: New Priorities], In Znanie. Ponimanie. Umenie [Knowledge. Understanding. Skill]. Available at: http://www.zpu-journal.ru/e-zpu/2011/3/Bolshakova_Russian_ Literature/ (accessed: 1 December 2016).

Cherniak, M. (2016). "Novyi realizm" sovremennoi prozy v kontekste russkogo traditsionalizma ["New Realism" of Modern Prose in the Context of Russian Traditionalism]. In Russkii traditsionalism: istoriia, ideologiia, poetika, literaturnaia refleksiia. Seriia "Universalii Kul'tury" [Russian Traditionalism: History, Ideology, Poetics, Literary Reflection. The "Universals of Culture” Series]. Moscow, 317-329.

Kargashin, I.A. (2013). "Velikii lad s okruzhaiushchim": khudozhestvennyi mir Mikhaila Tarkovskogo ["Great Harmony with the World": Mikhail Tarkovsky's Artistic World]. In 
Aktuelle Aspekte der Erforschung und Vermittlung der russischen Sprache und Literatur, Berlin, 205-216.

Kovtun, N.V. (2009). "Derevenskaia proza" v zerkale utopii [The "Village Prose" in the Mirror of Utopia]. Novosibirsk, $494 \mathrm{p}$.

Kovtun, N.V. (2011). Idillicheskii chelovek na perekrestkakh istorii: po proizvedeniiam A. Solzhenitsina, V. Rasputina, B. Ekimova, L. Petrushevskoi [The Idyllic Man at the Crossroads of History: as Exemplified by A. Solzhenitsyn's, V. Rasputin's, B. Ekimov's, L. Petrushevskaia's Works]. In Russkii proekt ispravleniia mira i khudozhestvennoe tvorchestvo [Russian Project of the World Rectification and Artwork of the 19th $-20^{\text {th }}$ Centuries], Moscow, 280-311.

Kovtun, N.V. (2013). Ikonicheskaia khristianskaia traditsiia v "Matreninom dvore" A. Solzhenitsina i "Izbe" V. Rasputina: problema avtorskogo dialoga [The Iconic Christian Tradition in A. Solzhenitsyn's "Matrena's House" and V. Rasputin's “Izba": the Problem of the Author's Dialogue], In Filologicheskii Klass [The Philological Class], 3 (33), 17-26.

Kovtun, N.V. Stepanova, V.A. (2015). Transformatsiia pogrebal'nogo obriada v pozdnikh rasskazakh V. Rasputina [Transformation of Obsequies in V. Rasputin's Late Novels], In Bulletin of Kemerovo State University, 2 (62), 144-152.

Lotman, Iu.M. (1988). V shkole poeticheskogo slova: Pushkin. Lermontov. Gogol [At the School of a Poetic Word: Pushkin. Lermontov. Gogol]. Moscow, 352 p.

Mitrofanova, A.A. (2009). Idilliia Mikhaila Tarkovskogo [The Idyll of Mikhail Tarkovsky]. In Sovremennost' v zerkale refleksii: iazyk-kul'tura-obrazovanie [Modernity in the Mirror of Reflection: Language-Culture-Education]. Irkutsk, ISU, 432-438.

Nikolina, N.A. (2002). Poetika russkoi avtobiograficheskoi prozy [Poetics of Russian Autobiographical Prose]. Moscow, 424 p.

Parte, K. (2004). Russkaia derevenskaia proza: svetloe proshloe [Russian Village Prose: the Bright Past]. Tomsk, Tomsk University Publishing House, 204 p.

Rusakov, E. (2004). Dobraia babushka i zlaia zhizn' [A Kind Granny and An Evil Life], In Krasnoiarskii Rabochii [Krasnoyarsk Worker], 115, 3-4.

Schastlivtseva, Iu.A. (2007). Proza Alekseia Varlamova 1980-1990-kh godov: zhanrovostilevoe svoeobrazie [Alexei Varlamov's Prose of the 1980-1990-ies: Genre and Stylistic Peculiarity]. Magnitogorsk, $21 \mathrm{p}$.

Stepanova, V.A. (2016). Khronotop prozy V. Rasputina [The Chronotope in V. Rasputin’s Prose]. In Russkii traditsionalizm: istoriia, ideologiia, poetika, literaturnaia refleksiia. Seriia "Universalii Kul'tury" [Russian Traditionalism: History, Ideology, Poetics, Literary Reflection. The "Universals of Culture" Series]. Moscow, 160-177.

Tarkovsky, M.A. (2014). Izbrannoe [Selected Works]. Novosibirsk, Publishing House "The Historical Heritage of Siberia", 496 p. 


\title{
Художественное время в малой прозе \\ М.А. Тарковского
}

Н.А. Вальянов

Красноярский государственный педагогический

университет им. В.П. Астафьева

Россия, 660049, Красноярск, ул. Ады Лебедевой, 89

\begin{abstract}
Статья посвящена проблеме художественного времени в малой прозе современного сибирского писателя М.А. Тарковского, чьё творчество критики и литературоведы относят к современному традиционализму. На примере ранних и зрельх текстов автора выведена общая типология художественного времени, выявлены его особенности. Особое внимание в художественном творчестве писателя уделяется поэтике кризисного и идиллического времени, потому как в ключевых текстах М.А. Тарковского очевиден своеобразный переход от хаоса и утраты традииионного к идее переосмысления национальных иенностей.
\end{abstract}

Ключевые слова: художественное время, хронотоп, неореализм, современная традиционалистская проза, деревенская проза, малая проза, Михаил Тарковский, современная русская лиmература.

Научная специальность: 10.00.00 - филологические науки. 